\title{
ANALISIS IDENTITAS KEMISKINAN MELALUI UNSUR NARATIF DALAM FILM "TURAH"
}

\author{
Marantika Gilang Asmoro \\ Siti Maemunah \\ Raden Roro Ari Prasetyowati
}

Jurusan Film \& Televisi, Fakultas Seni Media Rekam, Institut Seni Indonesia Yogyakarta Jl. Parangtritis km. 6,5 Yogyakarta Telp. (0274) 381047

\begin{abstract}
ABSTRAK
Kemiskinan merupakan salah satu permasalahan yang telah banyak diangkat menjadi sebuah karya audiovisual, salah satunya adalah Film Turah. Film ini terinspirasi dari kisah nyata kehidupan warga Kampung Tirang di Tegal yang miskin dan terisolasi. Penelitian yang berjudul Analisis Identitas Kemiskinan melalui Unsur Naratif dalam Film "T urah" bertujuan untuk memaparkan identitas kemiskinan yang dimunculkan dalam naratif film Turah. Penelitian ini menggunakan metode kualitatif deskriptif dengan pendekatan analisis naratif yaitu dengan mendeskripsikan unsur naratif dalam film Turah berupa plot, tokoh serta latar. Pengambilan data menggunakan purposive sampling dan ditemukan 28 sample scene yang akan dianalisis serta dipaparkan mengenai identitas kemiskinan.

Hasil penelitian ini menunjukkan bahwa film Turah menggunakan plot linear dengan penuturan sesuai urutan aksi peristiwa serta memiliki satu konflik utama pada tokoh sentral. Tokoh dalam film Turah memiliki 3 dimensi karakter yang menunjukkan identitas kemiskinan. Latar pada film Turah terdiri dari latar tempat, waktu, dan sosial-budaya. Film Turah memiliki bentuk narasi identitas kemiskinan berupa tidak memiliki faktor produksi, tidak mempunyai kemungkinan untuk memperoleh aset produksi, tingkat pendidikan rendah, tidak mempunyai fasilitas, dan berusia relatif muda serta tidak mempunyai keterampilan. Hal tersebut dinarasikan melalui problema sosial yang dialami oleh para tokoh yang menyebabkan kesenjangan dan munculnya berbagai macam konflik.
\end{abstract}

Kata Kunci : Kemiskinan, Naratif, Film Turah

\section{ABSTRACT}

Poverty is one of the problems that has been widely raised into an audiovisual work, one of which is the film Turah. This film is inspired by the true story of the life of the people of Kampung Tirang in Tegal who are poor and isolated. The study, entitled Poverty Identity Analysis through Narrative Elements in the Film "Turah" aims to describe the poverty identity that appears in the narrative of the film Turah. This study used a descriptive qualitative method with a narrative analysis approach, namely by describing the narrative elements in the Turah film in the form of plots, characters and settings. Data were collected using purposive sampling and found 28 sample scenes that will be analyzed and presented regarding the identity of poverty.

The results of this study indicate that the film Turah uses a linear plot with a narrative according to the sequence of events and has one main conflict with the central character. The character in the film Turah has 3 character dimensions that show the identity of poverty. The setting in the Turah film consists of place, time, and socio-cultural setting. The film Turah has a narrative form of poverty identity in the form of having no production factors, having no possibility of obtaining production assets, low education level, having no facilities, and being relatively young and without skills. This is narrated through the social problems experienced by the figures that cause gaps and the emergence of various kinds of conflicts. 


\section{Pendahuluan}

Kemiskinan merupakan salah satu permasalahan yang dihadapi oleh pemerintah negara Indonesia, dewasa ini pemerintah belum mampu menghadapi atau menyelesaikan permasalahan tersebut. Kemiskinan adalah kondisi kehidupan yang serba kekurangan yang dialami seseorang atau rumah tangga sehingga tidak mampu memenuhi kebutuhan minimal atau yang layak bagi kehidupannya. Kebutuhan dasar minimal yang dimaksud adalah yang berkaitan dengan kebutuhan pangan, sandang, perumahan dan kebutuhan sosial yang diperlukan oleh penduduk atau rumah tangga untuk memenuhi kebutuhan hidupnya secara layak (Ritonga, 2003:1).

Kemiskinan itu sendiri juga memiliki sebuah identitas dimana identitas tersebut merupakan suatu ciri atau keadaan khusus yang melekat pada diri seseorang dan atau sekelompok orang. Di sini khususnya adalah identitas kemiskinan yang ada di Indonesia. Meskipun saat ini Indonesia telah mengalami perkembangan teknologi yang pesat serta kemajuan pembangunan infrastruktur yang hampir merata di seluruh wilayah Indonesia, akan tetapi ternyata masih banyak daerah-daerah pelosok dan terpencil yang masih menyandang kategori daerah miskin dengan penduduk yang hidup dibawah kata layak.

Kemiskinan di Indonesia telah banyak diangkat menjadi sebuah karya audiovisual, baik itu program televisi, film fiksi, dokumenter, maupun konten youtube. Karya audiovisual yang paling populer saat ini adalah media film. Film merupakan sebuah karya seni dan industri yang semakin hari semakin berkembang pesat, tidak dapat dipungkiri bahwa film telah menjadi salah satu media komunikasi yang efektif di era modern seperti saat ini, sebagai media komunikasi yang bersifat audiovisual untuk menyampaikan suatu pesan kepada sekelompok orang atau masyarakat luas. Salah satu film yang mengangkat tentang kemiskinan di suatu daerah di Indonesia adalah film Turah.

Film Turah merupakan salah satu film lokal di produksi pada tahun 2016 oleh Fourcolours Films. Film ini merupakan film drama yang berdurasi 83 menit dan disutradarai oleh Wicaksono Wisnu Legowo serta diproduseri oleh Ifa Isfansyah. Yang membuat film ini berbeda dengan film-film lokal pada umumnya adalah bahasa yang digunakan dalam dialognya merupakan bahasa ngapak kota Tegal. Film Turah menceritakan tentang kehidupan masyarakat Kampung Tirang di Kota Tegal yang mengalami isolasi dan kemiskinan selama bertahun-tahun yang kemudian memunculkan berbagai problema.

Sementara itu, dalam kondisi yang sebenarnya (di luar konsep film Turah), Kampung Tirang merupakan sebuah 
kampung yang berdiri di atas tanah timbul seluas 13.581 meter persegi yang terletak di pesisir pantai utara, dekat dengan Pelabuhan Tegalsari Kota Tegal. Kampung ini dikelilingi oleh air laut dan termasuk wilayah kategori miskin serta terpencil. Listrik menyala hanya pada malam hari serta tidak ada air bersih. Kemiskinan di Kampung Tirang seolah-olah telah menjadi sebuah realitas yang membudaya dari tahun ke tahun.

Film Turah merupakan sebuah film fiksi yang mengambil cerita dan terinspirasi dari kisah nyata kehidupan masyarakat Kampung Tirang, Tegal, hanya saja sang sutradara membumbui cerita dengan tambahan beberapa adegan dan konflik untuk mengulur drama. Sesuai judul, film ini memiliki tokoh utama bernama Turah. Turah digambarkan sebagai sosok yang penyabar, santun, dan legowo. Uniknya, di dalam film Turah justru ada tokoh pembantu yang seolah dialah yang menjadi penggerak cerita di dalam film Turah. Tokoh tersebut bernama Jadag, dia digambarkan sebagai seorang yang kasar, keras kepala, dan ceroboh. Jadag selalu membawa alur konflik dari awal hingga akhir film.

Film Turah dipilih sebagai objek penelitian karena film ini merupakan film yang unik dengan penggunaan bahasa daerah yang masih sangat jarang, yaitu bahasa ngapak Kota Tegal, sehingga diharapkan dengan dilakukannya penelitian ini, bisa lebih mengenalkan bahasa ngapak itu sendiri kepada masyarakat luas. Film ini juga berhasil merepresentasikan gambaran kemiskinan yang ada di Indonesia. Selain itu, setting dalam film ini juga dikonsep dengan sangat natural.

Film ini pun telah banyak mengantongi beragam penghargaan, baik di festival nasional maupun internasional. Bahkan, film Turah sempat mewakili Indonesia di ajang Oscar 2018 kategori film Berbahasa Asing Terbaik Academy Awards ke-90. Menurut panitia seleksi, film Turah dipilih untuk mewakili Indonesia di ajang Oscar 2018 karena film tersebut syarat akan makna. Tak hanya itu, tokoh Jadag, yang diperankan oleh Slamet Ambari pun masuk ke dalam nominasi Aktor Pendatang Baru Terbaik dalam Indonesian Movie Actors Awards (IMMA) 2018. Penelitian ini akan memfokuskan pada analisis identitas kemiskinan yang ditunjukkan melalui unsur naratif dalam film Turah. Untuk membongkar hal tersebut akan dilakukan analisis plot, karakter, dan setting dalam film Turah.

Adapun penelitian lain yang menunjang penelitian ini untuk dijadikan sebagai bahan referensi dan rujukan yaitu Skripsi karya Neni Munthi Rima Sembiring Brahmana, mahasiswi Jurusan Televisi tahun 2012 Institut Seni Indonesia Yogyakarta dengan judul Perlawanan 
Perempuan Batak terhadap Budaya Patriarki dalam Film "Tiga Nafas Likas" (Analisis Naratif Film). Persamaan dengan penelitian ini adalah topik yang diangkat merupakan sebuah isu sosial dan metode yang digunakan merupakan metode kualitatif dengan pendekatan analisis naratif. Perbedaannya dalam penelitian ini adalah objek yang diteliti.

Rujukan penelitian selanjutnya adalah Skripsi karya Khaulah Izzaturobbaniyah, mahasiswi Jurusan Televisi tahun 2013 Institut Seni Indonesia Yogyakarta dengan judul Nilai Religius Pada Film Bulan Terbelah Di Langit Amerika Ditunjukkan Melalui Cerita (Analisis Unsur Naratif). Persamaan dengan penelitian ini adalah metode yang digunakan yaitu metode kualitatif dengan pendekatan analisis naratif. Sedangkan perbedaannya adalah objek yang diteliti serta topik yang diangkat di dalam penelitian. Tinjauan pustaka terakhir sebagai penunjang penelitian ini adalah Skripsi karya Shabrina Ophelia, mahasiswi jurusan Televisi tahun 2011 Institut Seni Indonesia Yogyakarta dengan judul Analisis Identitas Budaya Lokal Minangkabau Melalui Mise-En-Scene dan Dialog Pada "Film Tenggelamnya Kapan Van Der Wijck". Persamaan dengan penelitian ini adalah topik yang dibahas merupakan sesuatu yang berkaitan dengan identitas, sedangkan perbedaannya adalah objek yang diteliti dan alat yang digunakan untuk penelitian.

\section{Metode}

Metode penelitian yang akan digunakan adalah metode kualitatif deskriptif dengan pendekatan analisis naratif. Menurut (Sugiyono 2012:13) penelitian deskriptif kualitatif yaitu penelitian yang dilakukan untuk mengetahui nilai variabel mandiri, baik satu variabel atau lebih (independen) tanpa membuat perbandingan, atau menghubungkan dengan variabel yang lain. Dipilihnya metode penelitian ini karena analisis naratif melihat teks berita sebagai sebuah cerita, sebuah dongeng yang di dalam cerita ada plot, adegan, dan karakter. Selain itu, analisis naratif juga membantu untuk memahami bagaimana pengetahuan, makna dan nilai diproduksi serta disebarkan dalam masyarakat, termasuk dalam film Turah.

Analisis naratif memungkinkan untuk menyelidiki hal-hal yang tersembunyi dan laten dari suatu teks media. Peristiwa disajikan dalam bentuk cerita, dan dalam cerita tersebut sebenarnya terdapat nilai-nilai dan ideologi yang ingin ditonjolkan oleh pembuat film. Analisis naratif dapat pula dipakai untuk mengkaji struktur cerita dari narasi fiksi (seperti novel dan film) (Eriyanto, 2013:9). Secara umum, teknik analisis data menggunakan 
alur yang lazim digunakan dalam metode penelitian kualitatif yakni mengidentifikasi objek yang diteliti untuk dipaparkan, dianalisis, kemudian ditafsirkan maknanya. Dengan demikian, sebuah teks baru bisa disebut sebagai narasi apabila terdapat beberapa peristiwa atau rangkaian dari peristiwa-peristiwa.

Teknik pengambilan data untuk proses pengumpulan data yang digunakan dalam penelitian ini yaitu dokumentasi, observasi, dan studi kepustakaan. Proses dokumentasi mencatat berbagai sumber seperti video, foto, jurnal, artikel, dan data dari internet. Dokumentasi berguna sebagai bahan referensi dalam proses analisis data. Pengamatan dilakukan secara sistematis terhadap fenomena-fenomena yang diselidiki. Hasil dari rekaman objek penelitian akan diamati dan disinkronisasikan dengan topik yang dipilih pada penelitian yang akan dilakukan. Referensi kepustakaan dipergunakan sebagai pembanding dan sumber teori bagi penelitian yang sedang dilakukan. Teknik pengumpulan data dengan menggunakan literatur dan buku-buku yang berhubungan dengan unsur naratif film dan identitas kemiskinan, makalah, maupun sumber internet yang berhubungan dengan topik penulisan.

Kemudian akan dilakukan purposive sampling. Metode pengambilan sample menggunakan purposive sample; pengambilan sample secara sengaja berdasarkan adanya tujuan tertentu sesuai dengan persyaratan yang diperlukan. Pengambilan sample dengan teknik ini yaitu peneliti menentukan sendiri sehingga dapat mewakili populasi (Arikunto, 1997:127). Populasi penelitian ini adalah keseluruhan scene dalam Film Turah dari awal hingga akhir. Sample yang diambil dalam penelitian ini adalah scene-scene dalam Film Turah yang didalamnya dimunculkan identitas kemiskinan berdasarkan teori yang digunakan. Ada 77 scene dari keseluruhan film dari awal hingga akhir, dan ada 28 scene yang didalamnya terdapat identitas kemiskinan dalam cerita film Turah.

Teknik analisis data dalam penelitian ini adalah menggunakan teknik analisis naratif film, dimana peneliti akan membedah unsur-unsur naratif dalam film Turah. Unit analisis penelitian ini menggunakan satuan scene. Hasil analisis data disajikan secara deskriptif kualitatif yang merupakan paparan mengenai plot, tokoh/karakter, dan setting dalam setiap scene yang menunjukkan identitas kemiskinan dalam film Turah. Data yang dikumpulkan berupa kalimat dan bukan berupa angka.

\section{Pembahasan}

Berdasarkan metode purposive sampling ditemukan 28 scene yang memuat 
identitas kemiskinan tersebut yaitu scene 2, $4,5,6,7,8,11,12,13,14,16,19,22,24$, $25,27,28,35,36,40,49,52,60,64,66,68$, 73, dan 74. Pembahasan akan diawali dengan menganalisis unsur naratif dalam film Turah berupa penjabaran alur, karakter, dan setting. Setelah itu, dari hasil analisis unsur naratif kemudian akan dipaparkan analisis identitas kemiskinan berdasarkan sample scene yang dipilih dan dipaparkan bentuk narasinya.

\section{Analisis Unsur Naratif Film Turah}

\subsection{Alur Film Turah}

Plot atau alur adalah peristiwaperistiwa cerita yang mempunyai penekanan pada adanya hubungan kausalitas (Nurgiyantoro, 2013:167). Alur film Turah terbagi menjadi lima tahapan alur, yaitu:

Tabel 1. Tahapan Alur Film Turah

\begin{tabular}{|l|}
\hline \multicolumn{3}{|c|}{ Tahap Penyituasian } \\
Tahap ini memperkenalkan tokoh utama \\
dalam film yaitu Turah. Diperlihatkan juga \\
latar tempat dalam film, sebuah kampung \\
yang dikelilingi air laut, listrik hanya bisa \\
menyala pada malam hari dengan \\
menggunakan mesin diesel. \\
(Scene 1-5) \\
Tahap Pemunculan Konflik \\
Permasalahan mulai muncul saat rumah \\
Turah kedatangan petugas sensus, di sini \\
diketahui bahwa Kampung Tirang tidak \\
pernah mendapatkan fasilitas listrik dan air \\
bersih. Di sini ditunjukkan tidak adanya
\end{tabular}

perhatian pemerintah terkait problema yang ada di Kampung Tirang. Selain itu, masalah lain juga muncul ketika Turah diberi tugas oleh Darso untuk menjaga Kampung Tirang. (Scene 6-9)

\section{Tahap Peningkatan Konflik}

Konflik lain mulai bermunculan dan mengalami peningkatan ketegangan pada para tokoh. Dimulai dengan konflik Jadag bertengkar dengan istrinya, Turah yang harus mendengar Jadag meracau karena sedang mabuk, Jadag merasa iri kepada Pakel yang seorang sarjana dan memprovokasi Turah dan warga Kampung Tirang untuk melawan ketidakadilan, penemuan mayat bayi, Jadag bertengkar dengan Pakel, Jadag ketahuan berselingkuh oleh istrinya, sampai pada saat Pakel mulai meneror rumah Jadag dengan menyuruh orang untuk melempari botol kaca di halaman rumah Jadag.

(Scene 10-39)

\begin{tabular}{|c|}
\hline aks \\
\hline $\begin{array}{l}\text { Konflik mengalami titik puncak saat Jadag } \\
\text { marah-marah kepada Darso dan } \\
\text { menyampaikan segala uneg-unegnya. Jadag } \\
\text { menyampaikan bahwa Pakel hendak } \\
\text { mencelakai anak dan istrinya. Darso masih } \\
\text { membela Pakel dan mengatakan bahwa } \\
\text { Pakel bekerja menggunakan otak berbeda } \\
\text { dengan Jadag yang malas dan gemar mabuk- } \\
\text { mabukan. Jadag menganggap Darso pilih } \\
\text { kasih karena Jadag hanya tamatan SD. } \\
\text { Menurut Jadag warga Kampung Tirang tidak } \\
\text { membutuhkan Darso. Darso marah dan } \\
\text { menyuruh Agung untuk menghentikan } \\
\text { semua bantuan-bantuan kepada warga }\end{array}$ \\
\hline
\end{tabular}


Kampung Tirang. Setelah kejadian tersebut, Pakel tidak pernah terlihat lagi datang ke Kampung Tirang, sementara puncak konflik meningkat secara beruntun. Jadag meminta pembelaan kepada Turah, namun Turah enggan. Jadag tidak pulang ke rumah karena dia dipenjara akibat bertengkar dengan Pakel. Hal tersebut menyebabkan Turah telat pulang dan kampung gelap gulita. Rum pergi meninggalkan rumah, Jadag bersedih karena istrinya pergi tanpa pamit. Sampai puncaknya terjadi saat kampung diguyur hujan petir disertai angin, mesin diesel sulit menyala, sehingga para warga harus menggunakan lampu minyak. Sementara Jadag telah dibunuh oleh beberapa orang suruhan Pakel, Turah yang melihat hal tersebut diancam dan ia memilih untuk pergi dari kampung bersama istrinya. Saat itu juga listrik di Kampung Tirang mati.

(Scene 40-74)

\section{Tahap Penyelesaian}

Roji pulang dan melihat ayahnya, Jadag sudah tergantung di pohon depan rumahnya. Film ditutup dengan adegan Roji berjalan dan background suara kabar kematian Jadag. Pada tahap ini diperlihatkan nasib akhir dari tokoh Jadag. Menjadi tokoh yang terbunuh mampu mengakhiri konflik yang ada di dalam cerita film Turah, setidaknya menjadi hal yang lebih baik bagi warga Kampung Tirang yang lain.

(Scene 75-77)

\subsection{Tokoh dan Karakter dalam Film}

\section{Turah}

Tokoh atau karakter adalah penggerak jalan cerita. Penokohan merupakan gambaran watak dari seorang tokoh. Dalam film, terdapat beberapa pelaku yang memiliki karakterisasi, pemikiran maupun sikap tertentu.

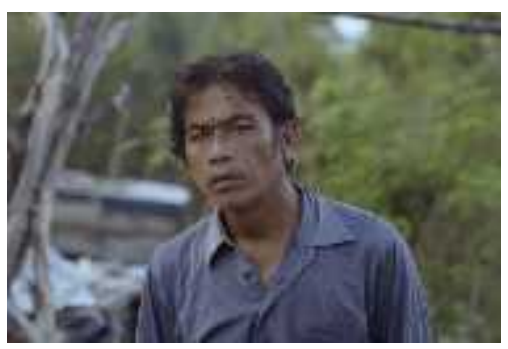

Gambar 1. Tokoh Turah

Turah merupakan tokoh utama yang menginginkan keteraturan dalam Kampung Tirang. Ia ingin hidup yang nyaman dan aman, tidak memikirkan kesenjangan yang sebenarnya sedang terjadi, yang terpenting bagi Turah adalah kehidupan yang tentram tanpa adanya konflik apapun.

a. Dimensi Fisiologis

Laki-laki paruh baya, berpostur tubuh ideal dengan kulit kusam sawo matang dan rambut berwarna hitam kecoklatan, lurus lepek.

b. Dimensi Psikologis

Turah merupakan seorang yang penyabar, santun, dan legowo. Namun, seringkali Turah juga mudah terprovokasi ucapan orang lain, terutama Jadag. Turah sangat ingin memiliki anak.

\section{c. Dimensi Sosiologis}


Turah tinggal berdua dengan istrinya di rumah sederhana. Ia merupakan pekerja tambak ikan dan diberi tugas menjaga keamanan Kampung Tirang oleh Darso. Hal itu disebabkan karena Darso sangat mempercayai Turah.

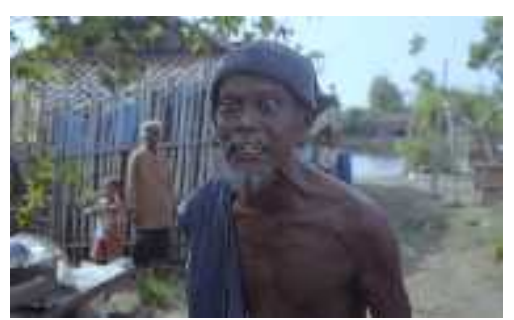

Gambar 2. Tokoh Jadag

Berlawanan dengan Turah, Jadag justru merupakan tokoh utama yang seolah berperan sebagai penggerak cerita secara penuh. Jadag memiliki ambisi untuk memberontak atas tindakan semena-mena yang dilakukan oleh Darso dan Pakel yang menurutnya telah memonopoli warga Kampung Tirang untuk kepentingan pribadinya. Jadag selalu membawa alur konflik dari awal hingga akhir cerita.

a. Dimensi Fisiologis

Laki-laki paruh baya, berpostur tubuh kurus, rambut, kumis, dan jenggotnya telah memutih. Kulitnya kusam berwarna gelap.

b. Dimensi Psikologis

Jadag merupakan seorang yang kasar dan keras kepala. Jadag sangat suka mencari masalah dengan orang lain. Dia mudah merasa iri dan sering bertindak ceroboh.

c. Dimensi Sosiologis
Jadag memiliki istri bernama Rum. Istrinya sedang hamil besar dan sebentar lagi akan melahirkan. Roji, anak pertamanya baru berumur 6 tahun. Jadag merupakan pekerja tambak dan pelelangan ikan. Ia juga sering melakukan pekerjaan serabutan sebagai tambahan penghasilan. Jadag memiliki kebiasaan mabuk-mabukan dan bermain togel. Ia juga berselingkuh dengan istri Darso.

Berdasarkan analisis tokoh dan karakternya, ditemukan dalam film Turah terdapat dua tokoh utama yaitu Turah dan Jadag, dan dua tokoh pendukung yaitu Darso dan Pakel. Keempat tokoh tersebut merupakan tokoh kunci yang membawa alur konflik dalam film Turah. Tokohtokoh dalam film Turah memiliki 3 dimensi karakter yang menunjukkan identitas kemiskinan. Hal tersebut dapat dilihat dari dimensi fisiologis, psikologis, dan sosiologis dari masing-masing tokohnya.

\subsection{Latar Film Turah}

Secara geografis, film Turah berlatar di sebuah kampung di pesisir utara Kota Tegal yang dikelilingi oleh air laut. Hal ini ditunjukkan dari beberapa scene establish yang menunjukkan kondisi sekitar Kampung Tirang. Latar tempat dari film Turah diperkuat dengan penggunaan bahasa ngapak kota Tegal yang khas sebagai dialognya. Latar tempat juga di tunjukkan dengan penggambaran rumah 
reot dan lingkungan yang kumuh. Di Kampung Tirang terdapat banyak tambak ikan dan gubug-gubug sederhana yang biasa digunakan untuk bekerja oleh Turah dan warga lain. Sementara itu, latar waktu dalam cerita film Turah adalah tahun 2016. Ditunjukkan di awal film pada scene 3 yaitu saat pemakaman Slamet tertera pada kayu nisannya tertulis ia meninggal di tahun 2016.

Film Turah menceritakan warga Kampung Tirang dengan kebiasaan sehariharinya yang monoton, mereka tidak memiliki adat istiadat serta peraturan yang berlaku di masyarakat. Mereka hanya ingin selalu hidup dalam zona nyaman dan bergantung kepada kebaikan Darso. Film Turah juga menunjukkan profesi dari mayoritas warga di sana dan di sekitar kampung yaitu nelayan, ditunjukkan dengan banyaknya kapal nelayan yang sering lewat. Selain nelayan, warga Kampung Tirang di film Turah juga berprofesi sebagai penjaga tambak, peternak, dan pekerja serabutan. Dalam kegiatan interaksi sosial antar tetangga, mereka masih cukup aktif dan gemar saling menolong satu sama lain.

\subsection{Analisis Identitas Kemiskinan}

Setelah melakukan analisis unsur naratif, selanjutnya akan dipaparkan analisis identitas kemiskinan yang ditunjukkan di dalam naratif film Turah dengan cara menjabarkan sampel scene yang dipilih berdasarkan teori dari Supriatna berkaitan dengan karakteristik kemiskinan. Film Turah memuat lima karakteristik kemiskinan, yaitu tidak memiliki faktor produksi sendiri, tidak mempunyai kemungkinan untuk memperoleh aset produksi dengan kekuatan sendiri, tingkat pendidikan rendah, tidak memiliki fasilitas, dan berusia relatif muda serta tidak memiliki keterampilan.

Hal tersebut ditunjukkan melalui beberapa sample scene yang berisi cerita, latar, tokoh dan karakter serta diperkuat dengan potongan dialog para tokohnya.

Tabel 2. Sampel Scene 12

Gambar 3. Scene 12
DARSO
kepribe?
Oohh, kie iwak nang balongan
TuRAH
(Oh, ikan di tambak bagamana?)
Mpun ageng-ageng gan. Wulan
ngajeng mpun saged panen. Sing
balongan teng kidul mriko. Nek
sing kulon mriku ya kinten-
kinten kalih wulan malih lah gan
mpun saged panen.
(Sudah besar-besar gan. Bulan
depan sudah bisa dipanen yang
tambak bagian selatan sana.
Kalau yang barat kira-kira dua
bulan lagi gan sudah bisa
panen.)
DARSo




\begin{tabular}{|c|}
\hline $\begin{array}{c}\text { (membuka topinya) } \\
\text { Ya syukurlah, kon butuh apa } \\
\text { maning nggo mbantu pegaweane } \\
\text { koen nang balongan? } \\
\text { (Ya syukurlah, kamu butuh } \\
\text { apalagi untuk membantu } \\
\text { pekerjaanmu di tambak?) }\end{array}$ \\
\hline $\begin{array}{l}\text { Dari potongan dialog antara Darso dan } \\
\text { Turah menunjukkan Turah bekerja } \\
\text { merawat ikan-ikan milik Darso. Darso } \\
\text { memberi modal kepada Turah untuk bisa } \\
\text { merawat ikan-ikan di tambak. Tidak } \\
\text { memiliki faktor produksi sendiri di sini } \\
\text { ditunjukkan melalui dimensi sosiologis } \\
\text { dari tokoh Turah dan Darso, dimana } \\
\text { Turah hanyalah seorang pekerja tambak } \\
\text { sedangkan Darso merupakan seorang } \\
\text { juragan. }\end{array}$ \\
\hline
\end{tabular}

Tabel 3. Sampel Scene 13

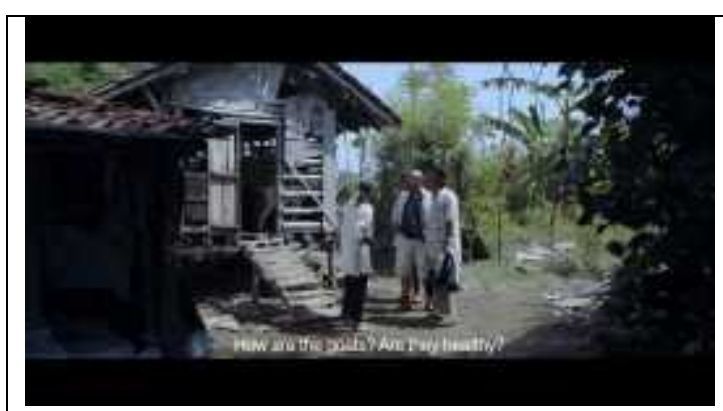

Gambar 4. Scene 13

DARSo
Ehh koen nang kono..
Pribe, wedhuse pada bergas kan?
(Eh kamu disitu. Bagaimana,
kambingnya sehat kan?)
KANDAR
Nggih, sae juragan.
Malah bada kaji taun niki mangke
saged disade sedoyo.
(Iya, bagus juragan. Malah
lebaran haji tahun ini nanti
bisa dijual semua)
DARSo

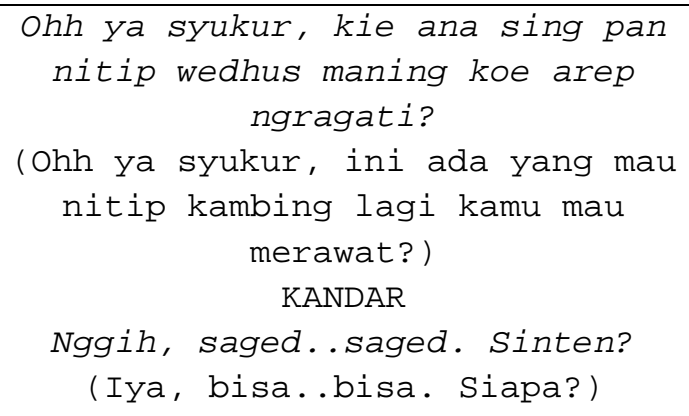

Scene 13 semakin memperkuat warga Kampung Tirang tidak memiliki faktor produksi sendiri. Kandar dipekerjakan oleh Darso untuk merawat kambingkambing milik orang lain. Sedangkan upah yang diperoleh oleh Kandar sangat sedikit. Dalam dialog di scene ini ditunjukkan bahwa film Turah menceritakan warga Kampung Tirang yang tidak memiliki faktor produksi berupa modal dan sumber informasi. Hal tersebut disebabkan karena Kandar tidak memiliki modal untuk memulai usahanya sendiri, semua modal diberikan oleh Darso. Kandar juga tidak memiliki sumber informasi yang luas berkaitan dengan orang-orang yang ingin menitipkan kambingnya kepada Kandar tanpa harus melalui perantara Darso, ia hanya sekedar menjalankan tugas yang diperintahkan oleh Darso.

Tabel 4. Sampel Scene 22

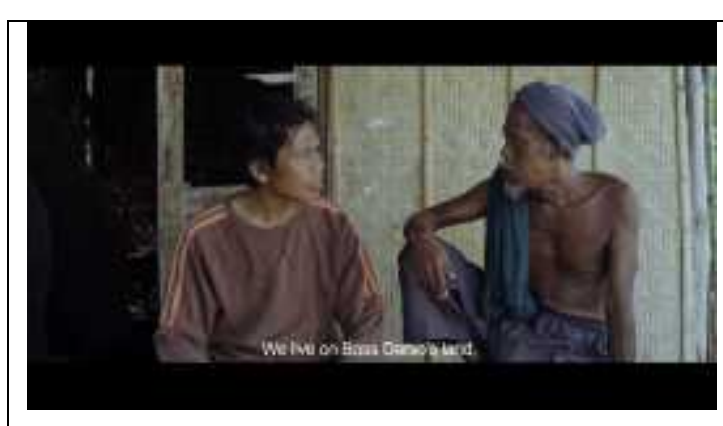




\begin{tabular}{|c|}
\hline Gambar 3. Scene 22 \\
\hline TURAH \\
Jeraku kaya kue tah lumrah o \\
Dag, wong dewek uripe ya nang \\
nduwur lemaeh juragan Darso. Ya \\
karepe kae sing nggawe aturan o, \\
pan motong pira pan motong pira. \\
Esih untung awake dewek diwei \\
pegawean dening juragan Darso. \\
(Menurutku seperti itu wajar \\
Dag, orang kita hidup juga di \\
atas tanahnya juragan Darso. Ya \\
terserah dia yang buat aturan, \\
mau motong berapa. Masih untung \\
kita diberi pekerjaan oleh \\
juragan Darso) \\
Secara garis besar film Turah telah \\
menceritakan warga Kampung Tirang \\
yang hidup bergantung kepada Darso \\
yang telah mengklaim tanah Kampung \\
Tirang sebagai tanah milik keluarganya. \\
Hal tersebut secara langsung berdampak \\
sangat signifikan terhadap kehidupan \\
warga Kampung Tirang. Mereka \\
otomatis tidak memiliki kekuatan dan \\
merasa tidak bisa memiliki aset sendiri, \\
seperti tanah dan aset lainnya, karena \\
mereka berasumsi bahwa tanah tempat \\
mereka tinggal adalah tanah milik Darso. \\
Termasuk tambak ikan dan seluruh lahan \\
yang ada. Padahal, menurut Jadag, tanah \\
yang mereka tinggali merupakan tanah \\
timbul milik pemerintah. \\
\hline
\end{tabular}

Tabel 5. Analisis Identitas Kemiskinan

\begin{tabular}{|c|c|c|c|}
\hline $\begin{array}{c}\text { Identitas } \\
\text { Kemiskinan }\end{array}$ & Alur & Tokoh & Latar \\
\hline $\begin{array}{l}\text { Tidak } \\
\text { memiliki } \\
\text { faktor }\end{array}$ & $\begin{array}{l}\text { Terdapat di } \\
\text { tahap }\end{array}$ & $\begin{array}{l}\text { Turah } \\
\text { Darso } \\
\text { Pakel }\end{array}$ & $\begin{array}{l}\text { Dekat } \\
\text { tambak } \\
\text { ikan. }\end{array}$ \\
\hline
\end{tabular}

\begin{tabular}{|c|c|c|c|}
\hline \multirow[t]{2}{*}{$\begin{array}{l}\text { produksi } \\
\text { sendiri. }\end{array}$} & \multirow{2}{*}{$\begin{array}{l}\text { peningkatan } \\
\text { konflik } \\
\text { (Scene } 12 \\
\text { dan scene } \\
\text { 13) }\end{array}$} & $\begin{array}{l}\text { (Scene } \\
12)\end{array}$ & \\
\hline & & $\begin{array}{l}\text { Turah } \\
\text { Darso } \\
\text { Pakel } \\
\text { Kandar } \\
\text { (Scene } \\
13 \text { ) }\end{array}$ & $\begin{array}{l}\text { Kandang } \\
\text { kambing. }\end{array}$ \\
\hline $\begin{array}{l}\text { Tidak } \\
\text { mempuny } \\
\text { ai } \\
\text { kemungki } \\
\text { nan untuk } \\
\text { memperol } \\
\text { eh aset } \\
\text { produksi } \\
\text { dengan } \\
\text { kekuatan } \\
\text { sendiri. }\end{array}$ & $\begin{array}{l}\text { Terdapat di } \\
\text { tahap } \\
\text { peningkatan } \\
\text { konflik } \\
\text { (Scene 22) }\end{array}$ & $\begin{array}{l}\text { Turah } \\
\text { Jadag } \\
\text { (Scene } \\
22 \text { ) }\end{array}$ & Gubug reot. \\
\hline \multirow{5}{*}{$\begin{array}{l}\text { Tingkat } \\
\text { pendidika } \\
\text { n rendah. }\end{array}$} & $\begin{array}{l}\text { Terdapat di } \\
\text { tahap } \\
\text { pemunculan } \\
\text { konflik } \\
\text { (Scene 6) }\end{array}$ & $\begin{array}{l}\text { Kanti } \\
\text { (Scene } \\
6 \text { ) }\end{array}$ & $\begin{array}{l}\text { Rumah } \\
\text { Turah. }\end{array}$ \\
\hline & \multirow{3}{*}{$\begin{array}{l}\text { Di tahap } \\
\text { peningkatan } \\
\text { konflik ( } \\
\text { Scene 14, } \\
\text { scene 25, } \\
\text { dan scene } \\
27 \text { ) }\end{array}$} & $\begin{array}{l}\text { Turah } \\
\text { Darso } \\
\text { Pakel } \\
\text { Sulis } \\
\text { (Scene } \\
14)\end{array}$ & $\begin{array}{l}\text { Rumah } \\
\text { Sulis. }\end{array}$ \\
\hline & & $\begin{array}{l}\text { Jadag } \\
\text { (Scene } \\
25)\end{array}$ & $\begin{array}{l}\text { Pemakaman } \\
\text { Kampung } \\
\text { Tirang. }\end{array}$ \\
\hline & & $\begin{array}{l}\text { Jadag } \\
\text { Pakel } \\
\text { (Scene } \\
27)\end{array}$ & $\begin{array}{l}\text { Di dekat } \\
\text { penyeberan } \\
\text { gan } \\
\text { Kampung } \\
\text { Tirang. }\end{array}$ \\
\hline & $\begin{array}{l}\text { Di tahap } \\
\text { klimaks } \\
\text { (Scene 40) }\end{array}$ & $\begin{array}{l}\text { Jadag } \\
\text { Darso } \\
\text { Agung } \\
\text { (Scene } \\
40)\end{array}$ & $\begin{array}{l}\text { Halaman } \\
\text { rumah } \\
\text { Jadag. }\end{array}$ \\
\hline
\end{tabular}




\begin{tabular}{|c|c|c|c|}
\hline \multirow{10}{*}{$\begin{array}{l}\text { Tidak } \\
\text { memiliki } \\
\text { fasilitas. }\end{array}$} & \multirow{3}{*}{$\begin{array}{l}\text { Terdapat di } \\
\text { tahap } \\
\text { penyituasian } \\
\text { (Scene } 2 \text {, } \\
\text { scene } 4 \text {, dan } \\
\text { scene 5) }\end{array}$} & \begin{tabular}{|l} 
Turah \\
(Scene \\
2 )
\end{tabular} & $\begin{array}{l}\text { Gubug } \\
\text { mesin } \\
\text { diesel. }\end{array}$ \\
\hline & & $\begin{array}{l}\text { Turah } \\
\text { Kanti } \\
\text { (Scene } \\
4 \text { ) }\end{array}$ & $\begin{array}{l}\text { Rumah } \\
\text { Turah. }\end{array}$ \\
\hline & & $\begin{array}{l}\text { Roji } \\
\text { (Scene } \\
5 \text { ) }\end{array}$ & $\begin{array}{l}\text { Perairan } \\
\text { pinggiran } \\
\text { kampung. }\end{array}$ \\
\hline & $\begin{array}{l}\text { Di tahap } \\
\text { pemunculan } \\
\text { konflik } \\
\text { (Scene 7) }\end{array}$ & $\begin{array}{l}\text { Sulis } \\
\text { (Scene } \\
7 \text { ) }\end{array}$ & $\begin{array}{l}\text { Kampung } \\
\text { Tirang. }\end{array}$ \\
\hline & \multirow{6}{*}{$\begin{array}{l}\text { Di tahap } \\
\text { peningkatan } \\
\text { konflik } \\
\text { (Scene } 11 \text {, } \\
\text { scene } 16 \text {, } \\
\text { scene } 19 \text {, } \\
\text { scene } 24 \text {, } \\
\text { scene } 27 \text {, } \\
\text { scene } 28, \\
\text { scene } 35, \\
\text { scene } 36 \text { ) }\end{array}$} & $\begin{array}{l}\text { Anak- } \\
\text { anak } \\
\text { Kampun } \\
\text { g Tirang } \\
\text { (Scene } \\
11)\end{array}$ & $\begin{array}{l}\text { Perairan } \\
\text { pinggiran } \\
\text { kampung. }\end{array}$ \\
\hline & & $\begin{array}{l}\text { Turah } \\
\text { Darso } \\
\text { Pakel } \\
\text { Agung } \\
\text { (Scene } \\
16)\end{array}$ & $\begin{array}{l}\text { Di } \\
\text { penyeberan } \\
\text { gan } \\
\text { Kampung } \\
\text { Tirang. }\end{array}$ \\
\hline & & $\begin{array}{l}\text { Turah } \\
\text { (Scene } \\
19)\end{array}$ & $\begin{array}{l}\text { Gubug } \\
\text { mesin } \\
\text { diesel. }\end{array}$ \\
\hline & & $\begin{array}{l}\text { Darso } \\
\text { Pakel } \\
\text { Agung } \\
\text { (Scene } \\
24)\end{array}$ & $\begin{array}{l}\text { Di } \\
\text { penyeberan } \\
\text { gan } \\
\text { Kampung } \\
\text { Tirang. }\end{array}$ \\
\hline & & $\begin{array}{l}\text { Pakel } \\
\text { Agung } \\
\text { (Scene } \\
\text { 27) }\end{array}$ & $\begin{array}{l}\text { Di } \\
\text { penyeberan } \\
\text { gan } \\
\text { Kampung } \\
\text { Tirang. }\end{array}$ \\
\hline & & $\begin{array}{l}\text { Nenek } \\
\text { Sulis } \\
\text { (Scene } \\
28)\end{array}$ & $\begin{array}{l}\text { Rumah } \\
\text { Sulis. }\end{array}$ \\
\hline
\end{tabular}

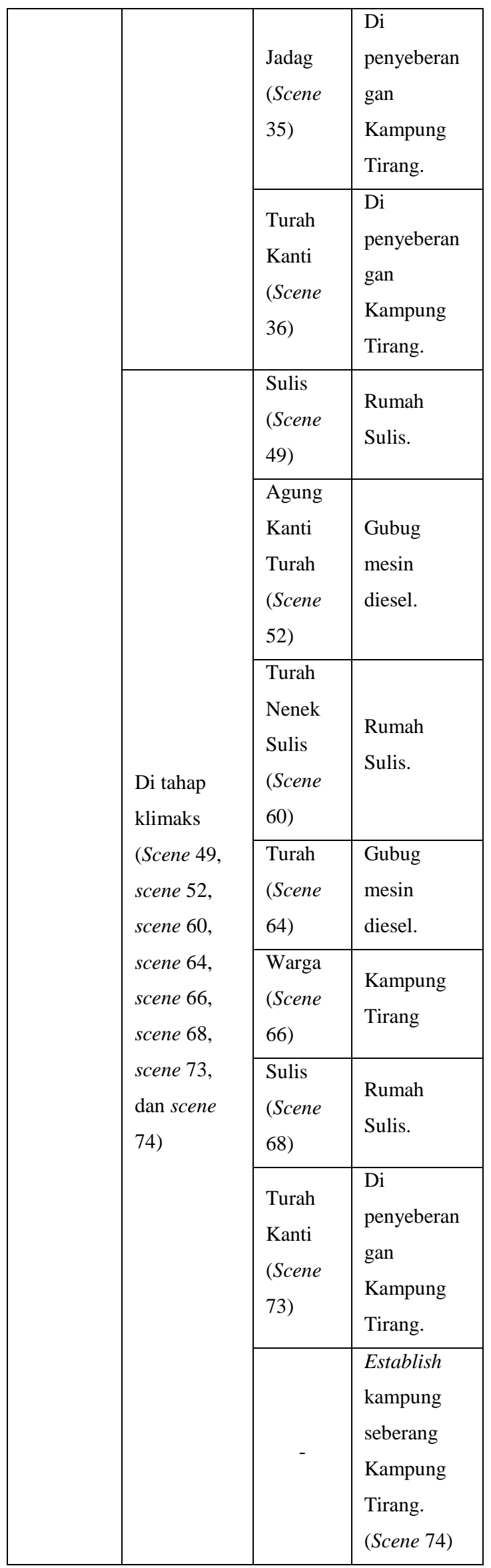




\begin{tabular}{|l|l|l|l|}
\hline Berusia & Terdapat di & & \\
relatif & tahap & Pakel & Di dekat \\
muda dan & pemunculan & Agung & genyebran \\
tidak & konflik & (Scene & Kampung \\
memiliki & $($ Scene 8$)$ & $8)$ & Tirang. \\
keterampil & & & \\
an. & & & \\
\hline
\end{tabular}

Identitas kemiskinan dalam film Turah dinarasikan dalam bentuk problema sosial yang terjadi dalam kehidupan warga Kampung Tirang. Film Turah menceritakan warga Kampung Tirang yang menyandang status miskin dimana mereka tidak memiliki faktor produksi karena mereka dipekerjakan oleh Darso dengan upah yang rendah. Selain itu, tanah timbul yang mereka tinggali juga diklaim sebagai tanah milik Darso yang menyebabkan warga Kampung Tirang tidak mempunyai aset produksi sendiri karena mereka berasumsi bahwa semua lahan Kampung Tirang adalah kepunyaan Darso meskipun pada faktanya tanah tersebut merupakan tanah timbul milik pemerintah. Hal tersebut yang menyebabkan warga Kampung Tirang sangat bergantung pada kebaikan Darso.

Jadag, tokoh yang secara eksplisit ditunjukkan sebagai seseorang yang selalu iri dengan kehidupan Pakel yang seorang sarjana, sedangkan Jadag sendiri tidak tamat Sekolah Dasar. Warga Kampung Tirang berpendidikan rendah, ditunjukkan dari pola pikir dan kebiasaan hidup mereka. Rendahnya tingkat pendidikan dalam film
Turah juga dinarasikan melalui tokoh Sulis yang tidak bersekolah, padahal ia merupakan anak perempuan yang seharusnya masih mengenyam bangku pendidikan. Sulis justru disibukkan mengurus neneknya di rumah.

Tidak adanya fasilitas yang memadahi di Kampung Tirang berupa fasilitas umum dan fasilitas sosial dinarasikan secara gamblang dari tidak adanya jaringan listrik dan air bersih, warga Kampung Tirang juga tidak memiliki fasilitas MCK (Mandi, Cuci, Kakus) yang baik. Tidak ada akses jalan yang mudah untuk menuju Kampung Tirang, melainkan harus menyeberang menggunakan rakit bambu. Selain itu, untuk mendapatkan fasilitas kesehatan warga Kampung Tirang juga bergantung kepada dokter yang datang ke kampung tersebut atau jika keadaan darurat, mereka harus menyeberang ke pusat kota untuk mendapatkan layanan kesehatan. Penggunaan obat tradisional menjadi ciri mereka tidak memiliki perlengkapan P3K. Anak-anak Kampung Tirang juga biasa bermain di perairan pinggiran kampung karena mereka tidak mempunyai fasilitas hiburan dan rekreasi. Tidak memiliki fasilitas dalam film Turah sangat berkaitan dengan latar tempat dalam film ini yaitu Kampung Tirang yang merupakan sebuah kampung yang berada di atas tanah timbul dan dikelilingi oleh air laut. Hal tersebut yang menyebabkan 
Kampung Tirang terisolasi dan sulit mendapatkan fasilitas.

Identitas kemiskinan juga dinarasikan melalui tokoh Agung, seorang remaja laki-laki yang masih berusia relatif muda namun sudah mengerjakan pekerjaan serabutan yang kasar dan mengandalkan tenaga serta kekuatan fisik, hal tersebut disebabkan karena Agung tidak memiliki keterampilan yang spesifik yang dapat digunakan untuk mencari pekerjaan yang lebih layak.

\section{Kesimpulan}

Setelah melakukan analisis terhadap data yang ada, maka dapat disimpulkan bahwa film Turah memuat narasi identitas kemiskinan. Hal tersebut dapat dilihat dari unsur naratif pada film Turah. Melalui analisis naratif dapat diketahui bahwa terdapat pesan ataupun ideologi yang ingin disampaikan oleh pembuat film kepada penonton. Adapun unsur naratif dalam film Turah adalah sebagai berikut:

1. Unsur naratif dalam film Turah.

Unsur naratif yang dipilih untuk menganalisis film Turah adalah plot, karakter, dan latar/setting.

a. Plot

Plot dalam film Turah menggunakan pola lurus atau linear yaitu dengan penuturan sesuai urutan aksi peristiwa yang secara eksplisit menceritakan kehidupan warga
Kampung Tirang yang pada dasarnya memiliki satu konflik utama pada tokoh sentral Turah dan Jadag, konflik tersebut berupa kemiskinan yang menyebabkan timbulnya berbagai problema sosial. Plot dalam film Turah terbagi menjadi lima tahapan, yaitu tahap penyituasian, tahap pemunculan konflik, tahap peningkatan konflik, tahap klimaks, dan tahap penyelesaian.

b. Tokoh/Karakter

Tokoh dalam film Turah memiliki 3 dimensi karakter yang menunjukkan identitas kemiskinan. Hal tersebut dapat dilihat dari dimensi fisiologis, psikologis, dan sosiologis dari masing-masing tokohnya.

c. Latar/Setting

Latar yang digunakan dalam film Turah adalah sebuah kampung yang berdiri di atas tanah timbul milik pemerintah di pesisir utara Kota Tegal yang dikelilingi oleh air laut. Latar tempat diperkuat dengan penggunaan bahasa ngapak Kota Tegal yang khas dalam dialognya. Selain itu, tempat dalam film Turah juga ditunjukkan dengan penggambaran rumah reot dan lingkungan yang kumuh. Di Kampung Tirang banyak terdapat tambak ikan dan gubug-gubug sederhana sebagai tempat bekerja 
beberapa warga. Latar waktu dalam film Turah disesuaikan dengan tahun produksi film yaitu tahun 2016. Film Turah menceritakan warga Kampung Tirang dengan kehidupannya yang monoton tanpa adanya adat istiadat ataupun peraturan yang berlaku di masyarakat. Latar pada film Turah juga menunjukkan mayoritas profesi warga disana yaitu nelayan. Selain nelayan, warga Kampung Tirang di film Turah juga berprofesi sebagai pekerja tambak, peternak dan buruh serabutan.

2. Bentuk Narasi Identitas kemiskinan dalam film Turah.

Berdasarkan penjabaran unsur naratif yang telah dilakukan, dapat diambil kesimpulan bahwa film Turah memiliki narasi identitas kemiskinan di dalamnya yang ditunjukkan dari 28 sample scene berdasarkan teori Supriatna, dengan hasil analisis antara lain:

a. Tidak memiliki faktor produksi sendiri.

Warga Kampung Tirang di cerita film Turah tidak memiliki faktor produksi sendiri karena Darso mempekerjakan mereka sebagai buruh dengan upah rendah.

b. Tidak memiliki kemungkinan untuk memperoleh aset produksi dengan kekuatan sendiri.
Warga Kampung Tirang berasumsi bahwa tanah yang mereka tinggali adalah tanah milik Darso. Hal tersebut yang membentuk pola pikir bahwa mereka hidup bergantung kepada Darso, karena mereka tidak memiliki aset produksi sendiri seperti tanah, tambak, dan lain-lain.

c. Tingkat pendidikan rendah.

Warga Kampung Tirang memiliki tingkat pendidikan yang rendah ditunjukkan secara eksplisit pada tokoh Jadag yang selalu iri kepada Pakel yang seorang sarjana, sedangkan Jadag sendiri tidak tamat Sekolah Dasar. Selain itu, Sulis, seorang anak yang seharusnya masih bersekolah, tidak pernah terlihat berangkat ke sekolah di sepanjang film dari awal hingga akhir, ia justru disibukkan dengan mengurus neneknya.

d. Tidak memiliki fasilitas.

Warga Kampung Tirang tidak memiliki fasilitas yang terdiri dari fasilitas umum dan fasilitas sosial. Fasilitas umum yang tidak dimiliki oleh warga Kampung Tirang di antaranya fasilitas jaringan listrik, air bersih, transportasi, dan fasilitas MCK, sedangkan fasilitas sosial yang tidak dimiliki warga Kampung Tirang adalah fasilitas kesehatan 
serta fasilitas taman rekreasi dan hiburan.

e. Berusia relatif muda dan tidak memiliki keterampilan.

Film Turah memunculkan tokoh bernama Agung, dimana ia masih berusia muda namun sudah bekerja serabutan yang hanya mengandalkan tenaga dan kekuatan fisik, hal tersebut dikarenakan Agung tidak memiliki keterampilan yang spesifik sehingga tidak mampu memperoleh pekerjaan yang lebih layak.

\section{Daftar Pustaka}

Arikunto, Suharsimi. Prosedur Penelitian (Suatu Pendekatan Praktek). Jakarta: Rineka Cipta,1997.

Berger, Arthur Asa. Media and Society: A Critical Perspective. Boulder: Rowman\&Littlefield Publishers, 2003.

Bordwell, D., Thompson, K. Film Art: An Introduction ( $8^{\text {th }}$ Edition). London: McGraw Hill, 2008.

Chambers, Robert. Rural Development, Putting the Last First. London: Longman, 1983.

Effendy, Onong Uchjana. Dinamika Komunikasi. Bandung: PT Remaja Rosdakarya, 1986.

Egri, Lajos. The Art of Dramatic Writing. New York: A Thouchstone Book, 1960.

Eneste, Pamusuk. Novel dan Film. Flores: Penerbit Nusa Indah, 1991.

Eriyanto. Analisis Naratif: Dasar-dasar dan Penerapannya dalam Analisis
Teks Berita Media. Jakarta: Prenada Media Group, 2013.

Griffin, R. W., dan Ebert, R. J. Bisnis. Jakarta: Erlangga, 2006.

Lutters, Elizabeth. Kunci Sukses Menulis Skenario. Jakarta: Grasindo, 2010.

Martani, Dwi. Akuntansi Keuangan Menengah Berbasis PSAK. Jakarta: Salemba Empat, 2012.

Nurgiyantoro, Burhan. Teori Pengkajian Fiksi. Yogyakarta: Gadjah Mada University Press, 2013.

Pratista, Himawan. Memahami Film. Yogyakarta: Homerian Pustaka, 2008.

Ritonga, Hamonangan. Perhitungan Penduduk Miskin. Jakarta: Badan Pusat Statistik, 2003.

Seger, Linda. Making a Good Script Great. New York: Samuel France Trade, 1987.

Suban, Fred. Yuk...Nulis Skenario Sinetron: Panduan Menjadi Penulis Skenario Sinetron Jempolan. Jakarta: Gramedia Pustaka Utama, 2009.

Sugiyono. Metode Penelitian Kuantitatif Kualitatif dan $R \& D$. Bandung: Alfabeta, 2012.

Sukmadinata, Nana Syaodih. Metode Penelitian Pendidikan. Bandung: PT. Remaja Rosdakarya, 2011.

Supriatna, Tjahya. Birokrasi Pemberdayaan dan Pengentasan Kemiskinan. Bandung: Humaniora Utama Press (HUP), 1997.

Wiyanto, Asul. Terampil Bermain Drama. Jakarta: Grasindo, 2002. 